\title{
RELATIVE EFFECTIVENESS OF GAMEXAN AND PERMETHRINE AS ANTI-SCABIES, CONTROLLING FOR GENDER AND PERSONAL HYGIENE EDUCATION
}

\author{
Feny Tunjungsari'1), Didik Tamtomo²), Bhisma Murti²) \\ 1) Department of Public Health, Muhammadiyah University at Malang \\ 2) Masters Program in Family Medicine, Sebelas Maret University
}

\begin{abstract}
BACKGROUND: Prevalence of scabies remained high in slum areas and certain communities (e.g. religious boarding school). Incidence of scabies is associated with poor personal hygiene. Scabies is curable. This study aimed to determine the relative effectiveness between Gamexan and Permethrine as anti-scabies and effect modification by personal hygiene education.

SUBJECT AND METHODS: This was a double-blinded randomized controlled trial, conducted in Malang district. A sample of 40 students aged 12-18 years old from a religious boarding school in Malang district was selected at random for this study. The dependent variable was cure from scabies. The independent variable included anti-scabies (Gamexan and Permethrine), sex, and personal hygiene education. A multiple logistic regression was used to analyze the data.

RESULTS: After controlling for the effects of gender and personal hygiene education, Gamexan was 1/3 less likely to cure scabies than Permethrine $(\mathrm{OR}=0.38 ; 95 \% \mathrm{CI}=0.12$ to $1.19 ; \mathrm{p}=0.096)$. Female gender $(\mathrm{OR}=8.13 ; 95 \% \mathrm{CI}=0.87$ to $76.24 ; \mathrm{p}=0.067)$ and personal hygiene education $(\mathrm{OR}=9.37 ; 95 \% \mathrm{CI}=2.92$ to $30.07 ; \mathrm{p}<0.001)$ increased the chance of cure. The effect of anti-scabies treatment on cure was modified by personal hygiene and education. The odd of cure with Permethrine was 3 times as many than Gamexan when personal hygiene education was not provided $(\mathrm{OR}=3.27 ; 95 \% \mathrm{CI}=0.80$ to $13.35 ; \mathrm{p}=0.046)$. The odd of cure with Permethrine was 1.42 times as many than Gamexan when personal hygiene education was provided $(\mathrm{OR}=1.42 ; 95 \% \mathrm{CI}=0.27$ to $7.34 ; \mathrm{p}=$ 0.339).

CONCLUSION: Permethrine is three times more effective as anti-scabies than Gamexan when personal hygiene was not provided. This difference in effectiveness between the two anti-scabies treatments was not significant when personal hygiene was provided. Female gender and personal hygiene education increase the chance of cure.
\end{abstract}

Keyword: scabies, Gamexan and Permethrine, sex, personal hygiene education, effect modification 